\title{
Physiological Assessment of Water Stress in Potato Using Spectral Information
}

\author{
Angela P. Romero, Andrés Alarcón, Raúl I. Valbuena and Carlos H. Galeano* \\ Centro de Investigación Tibaitatá, Corporación Colombiana de Investigación Agropecuaria (CORPOICA), Mosquera, \\ Colombia
}

Water stress in potato (Solanum tuberosum L.) causes considerable losses in yield, and therefore, potato is often considered to be a drought sensitive crop. Identification of water deficit tolerant potato genotypes is an adaptation strategy to mitigate the climatic changes that are occurring in the Cundiboyacense region in Colombia. Previous studies have evaluated potato plants under water stress conditions using physiological analyses. However, these methodologies require considerable amounts of time and plant material to perform these measurements. This study evaluated and compared the physiological and spectral traits between two genotypes, Diacol Capiro and Perla Negra under two drought levels (10 and 15 days without irrigation from flowering). Reflectance information

OPEN ACCESS

Edited by:

Erik Harry Murchie,

University of Nottingham,

United Kingdom

Reviewed by:

Edmundo Acevedo,

University of Chile, Chile

Shawn Carlisle Kefauver,

University of Barcelona, Spain

*Correspondence:

Carlos H. Galeano

cgaleano@corpoica.org.co

Specialty section:

This article was submitted to

Plant Abiotic Stress,

a section of the journal

Frontiers in Plant Science

Received: 06 March 2017 Accepted: 04 September 2017 Published: 20 September 2017

Citation:

Romero AP, Alarcón A, Valbuena Rl and Galeano CH (2017) Physiological Assessment of Water Stress in Potato

Using Spectral Information.

Front. Plant Sci. 8:1608. doi: 10.3389/fpls.2017.01608 was used to calculate indexes which were associated with the physiological behavior in plants. The results showed that spectral information was correlated $(\rho<0.0001)$ with physiological variables such as foliar area $(\mathrm{FA})$, total water content $\left(\mathrm{H}_{2} \mathrm{Ot}\right)$, relative growth rate of potato tubers (RGTtub), leaf area ratio (LAR), and foliar area index (AFI). In general, there was a higher concentration of chlorophyll under drought treatments. In addition, Perla Negra under water deficit treatments did not show significant differences in its physiological variables. Therefore, it could be considered a drought tolerant genotype because its physiological performance was not affected under water stress conditions. However, yield was affected in both genotypes after being subject to 15 days of drought. The results suggested that reflectance indexes are a useful and affordable approach for potato phenotyping to select parent and segregant populations in breeding programs.

Keywords: drought tolerance, yield, potato breeding, reflectance indexes, correlation, stomatal conductance

\section{INTRODUCTION}

Potato (Solanum tuberosum L.) is the fourth most important food crop in the world (FAO, 2011). It plays an important role as a food supply in developing countries because it is an affordable and rich source of carbohydrates. In Colombia, the average potato per capita consumption is more than 62 $\mathrm{kg} /$ year, so it is a fundamental diet element for the population. The country produces between 1.8 and 2 million tons of potato per year with an average yield of 19 ton/ha (DANE-ENEA, 2014). However, the demand for potato is growing for both fresh and processed markets. Therefore, breeders have several challenges to address such as finding high-yielding potato cultivars adapted to climate change; currently in the country's potato growing areas extreme weather events like droughts are becoming more frequent and are causing greater crop losses. The effects of climate change will be particularly pronounced in lower-latitude regions where most developing countries 
are located. In Africa, Asia and Latin America for instance, yields could decline between 20 and $40 \%$ in the future if no effective adaptation measures are taken (FAO, 2011). Specifically in Colombia, a good portion of the agro-ecosystems suitable for potato production are vulnerable to increased aridity, soil erosion, desertification, and variations in the hydrological system as consequence of climate change (United Nations Development Programme (UNDP), 2010). Therefore, potato breeders have to find new cultivars resistant to both biotic and abiotic stresses and, at the same time, they must guarantee that these possess high yielding and good tuber qualities, and with good producer, market and consumer acceptance.

There are many physiological variables used to evaluated water stress in plants. For instance, gas exchange is the method that most researchers use to study drought responses. This approach is based on the fact that drought stress reduces stomatal conductance in potato when leaf water potential values fall below -0.6 MPa (Ahmadi et al., 2010). In addition, a range of low photosynthetic rate values between 1 and $3.6 \mu \mathrm{CO}_{2} \mathrm{~m}^{-2} \mathrm{~s}^{-1}$ have been used to describe water stress conditions in potato grown in greenhouses under natural light (Vasquez-Robinet et al., 2008). Similarly, in well tuberized potatoes the response of the photosynthetic rate to drought depends on mesophyll conductance (Schapendonk et al., 1989), relative water content (RWC) and light intensity (Basu et al., 1999).

On the other hand, canopy spectral reflectance is based on the differential pattern of light reflectance on leaves at photosynthetically active $(400-700 \mathrm{~nm})$ and infrared (700$1,000 \mathrm{~nm}$ ) wavelengths (Bowman et al., 2015). Additionally, much more specific narrow-band regions such as the red edge (maximum slope of vegetation reflectance from 690 to $740 \mathrm{~nm}$ ) for predicting plant stress have been used (Clay et al., 2006). Thus, spectral vegetation indexes were designed to evaluate vegetation condition, foliage, cover, phenology and drought monitoring (Padilla et al., 2011), as well as leaf nitrogen (N) (Pilon et al., 2010), photosynthetic characteristics (Aparicio et al., 1999), chlorophyll content and plant water status (Kokaly et al., 2003; Rosso et al., 2005; Gutierrez et al., 2010). Although attempts to develop indexes based on a mathematical function of the amount of reflected light at various wavelengths to be used as a water status proxy have been successfully applied (Zygielbaum, 2009), it is necessary to conduct more studies to standardize the use of this technique for each specific crop and type of stress.

Vegetation indexes have widely been reviewed in literature (Milton et al., 2007; Ahmad, 2012). The ones that need to be highlighted are the normalized vegetation index (NDVI) that is associated with canopy density (i.e., leaf area or percent cover) or total biomass (Verhulst and Govaerts, 2010), the simple ratio (SR) that is related to changes in the amount of green biomass and pigment content, i.e., high values for healthy vegetation and low ones for soil, water, etc. (Tucker and Sellers, 1986). The photochemical reflectance index (PRI) measures the xanthophyll cycle activity which is related to photosynthetic light-use efficiency in plants (Coops et al., 2010). Studies have demonstrated that the PRI is a physiological index sensitive to the epoxidation state of the xanthophyll cycle pigments and to photosynthetic efficiency, serving as a proxy for short-term changes in photosynthetic activity, stress conditions, and pigment absorption, but is highly affected by illumination conditions, viewing geometry and canopy structure (Hernández-Clemente et al., 2011). The pigment-specific simple ratio of chlorophyll-a (PSSRa) measures chlorophyll-a content and has been used for estimating vegetative biomass (Babar et al., 2006b). The reflectance water index (WI) is defined as the ratio between the reflectance at a water band wavelength $(900 \mathrm{~nm})$ to a reflectance wavelength where there is no absorption due to water content variability $(970 \mathrm{~nm})$ (Prasad et al., 2007). The normalized water index 1 (NWI1), the normalized water index 2 (NWI2), the normalized water index 3 (NWI3) and the normalized water index 4 (NWI4) are an alternative approach to select high yielding lines for diverse environments (Babar et al., 2006b; Prasad et al., 2007). The previous four indexes are defined as the Oryza $\mathrm{N}$ index (ONI) and they are useful for the nondestructive monitoring and diagnosis of plant $\mathrm{N}$ status. Lastly, the dry Zea N index (DZNI) is used for the early detection of $\mathrm{N}$ deficiency in plants (Bowman et al., 2015). Specifically in potato, spectral information has been used to identify $\mathrm{N}$ rate (Booij and Uenk, 2004; Bowen et al., 2005; Van Evert et al., 2012) and water content (Elbatawi et al., 2008). Additionally, near-infrared reflectance was used to estimate the proportion of ground covered by potato canopy (Bouman et al., 1992).

Regarding drought stress information high phenotyping costs to get accurate data has been a huge bottleneck. Therefore, spectral-related data have instead been used to calculate vegetation indexes that have shown correlation to plant growth, yield and early detection of biotic or abiotic stress in plants, allowing the early and quick evaluation of a wide variety of cultivars. Spectroscopy in particular, has the capacity to detect different materials by discriminating their reflectance information. For instance in plant physiology, reflectance information has been widely used to determine plant health, water content, environmental stress, and other agronomic traits (Ceccato et al., 2001; Campbell et al., 2007; Nijland et al., 2014).

It is well known that drought limits crop plants' productivity by affecting photosynthetic processes at the canopy, leaf or chloroplast levels, either directly or by feedback inhibition if photosynthetic transport to sink organs is limited (Jones and Corlett, 1992). Baracaldo et al. (2014) showed that when plants suffered transpiration reduction, some adaptations to abiotic stress were among others, leaf yellowing, epinasty and abscission. Tuber production generally correlates with the plant's available water content; however, some genotypes produce higher yields than others under limited water supply. Considerable variation in drought tolerance has been found in potato varieties, elite clones, landraces and wild relatives (Schafleitner et al., 2007; Coleman, 2008). Vasquez-Robinet et al. (2008) found that individuals of $S$. tuberosum spp. andigena showed more drought tolerance compared to individuals of $S$. tuberosum spp. tuberosum, and this has been attributed to the induction of heat shock proteins and antioxidant genes encoding proteins in the chloroplast, as well as genes for anthocyanin synthesis and transport that could be important in case of repeated stress. These findings confirm the putative roll of anthocyanins and their importance 
in ameliorating environmental stresses induced by drought (Chalker-Scott, 1999).

Furthermore, drought phenotyping studies in potato have been carried out using biomass traits, yield components and physiological indexes (Saravia et al., 2016). However, as these evaluations involved destructive sampling and considerable amount of labor, it is necessary to find an affordable and accurate alternative to such methods, as spectral reflectance to evaluate water stress in plants. Still, the use of high-throughput phenotypic testing, specifically spectral reflectance, has been limited (Dammer et al., 2016). Therefore, the aims of this study are: (1) to evaluate spectral reflectance indexes for potato drought evaluation, and (2) compare the drought responses of two purple and red skin potato genotypes within the Andigena group. The present study will provide results and information regarding the use of spectral indexes related with physiological variables in potato to identify drought resistance genotypes and develop a useful tool for plant phenotyping.

\section{MATERIALS AND METHODS}

\section{Plant Material}

Two potato genotypes belonging to the Solanum tuberosum L. group andigena were used in this study: Diacol Capiro (also known as R12) and Perla Negra (CIP code No 391691-96 and called Serranita in Peru), both have semi-erect growth habit. Diacol Capiro is the most widely cultivated variety for fresh markets and for the industry in Colombia. The tuber skin is predominantly red with purple as a secondary color, and the flesh color is cream. Perla Negra was a recently introduced material from the International Potato Center CIP under the international project "Innovation and Development Network" toward the efficient dissemination and pro-poor impact mechanisms with new potato varieties in the Andean zone. Specifically, Perla Negra has a purple skin and a pale yellow flesh and its high content of anthocyanin will be an indicator of potential drought tolerance.

\section{Experimental Conditions}

The experiments were conducted at the facilities of Corporacion Colombiana de Investigación Agropecuaria (CORPOICA) in the research center C. I. Tibaitatá ( $14 \mathrm{Km}$ via Mosquera, Colombia, $4^{\circ} 41^{\prime} 45^{\prime \prime} \mathrm{N}$ and $74^{\circ} 12^{\prime} 12^{\prime \prime} \mathrm{W}$ ), from the end of June to November 2015. The trials were carried out in a glasshouse with controlled conditions. The minimum and maximum daily temperatures were 14.04 and $19.32^{\circ} \mathrm{C}$, respectively, and the atmospheric relative humidity varied between 48.3 and $82.4 \%$. The daily average solar radiation was $7.4,7.0,6.9$, and $6.8 \mathrm{MJm} 2{ }^{*} \mathrm{~d}^{-1}$ in August, September, October and November, respectively (WatchDog 2900ET Weather Station, Aurora, IL).

Tubers were planted in pots $(20 \mathrm{~L})$ filled with $14 \mathrm{~kg}$ of soil $(5.36$ $\left.\mathrm{pH}, 0.40 \mathrm{ds} . \mathrm{m}^{-1}, 14.23 \% \mathrm{OM}\right)$. Each pot was fertilized with $40 \mathrm{~g}$ of Triple-15 (15\% N, 15\% P and 15\% K) and $5 \mathrm{~g}$ of Sulfomag ${ }^{\circledR}$ per seedling. Additionally, nutrient solutions were added 15, 21, and 42 days after emergence (dae) following the methodology reported by Mateus (2010).

Soil moisture was controlled using a tensiometer (Soilmoisture Equipment Corp, USA) and the watering of each pot was carried out with a test tube according to the tensiometer's readings. The soil water potential in the control did not decline bellow $-0.03 \mathrm{MPa}$. Three treatments were applied to each genotype: a control treatment in which the substrate was maintained at field capacity (soil water potential did not decline below $-0.03 \mathrm{MPa}$ ), and two water restriction treatments that started 10 and 15 days from tuber initiation (60 dae) (Table 1). Finally, after treatments were applied plants were well watered until harvest.

A randomized complete block design was used with four replicates and six plants per treatment. Four destructive samplings were carried out ( 4 plants per treatment) before water restriction was initiated (60 dae), at the end of each water restriction treatment (70 and 75 dae) and after watering (95 dae).

\section{Gas Exchange}

Physiological measurements were made on expanded and sunexposed leaves located in the middle third section of the plant. Gas exchange was measured using a portable photosynthesis system CIRAS 3 (PP Systems, USA) under ambient light (cuvette details: area $1.5 \mathrm{~cm}^{2}, \mathrm{CO}_{2} 400 \mathrm{ppm}$, temperature $22^{\circ} \mathrm{C}$, cuvette flow rate $300 \mathrm{cc}$ min- 1 and relative humidity $50 \%$ ), obtaining values for net photosynthesis (A), stomatal conductance $\left(g_{s}\right)$, internal leaf $\mathrm{CO}_{2}(\mathrm{Ci})$, vapor pressure deficit (VPD), transpiration (E) and water-use efficiency (WUE = A. $E^{-1}$ ), the later according to Hunt (1982), and following the user manual version 1.06. All measurements were taken from 11:00 to 13:00 ensuring the high light intensity. It is based on a previous characterization during 8 days measuring gas exchange each hour since 8:00 to 16:00 (data not shown). The ceptometer and CIRAS3 have their own PAR sensor.

\section{Chlorophyll Concentration, Water Content, and Leaf Area Index}

Chlorophyll concentration (ChlSPAD) was estimated using a portable chlorophyll content meter CCM-200 (Opti-Sciences, USA). The data collected corresponded to the green color content of a leaf, and its value was equivalent to the amount of light transmitted by the leaf in two regions of the red and infrared wavelengths. The amount of red light absorbed indicated the quantity of chlorophyll, whereas the quantity of light absorbed next to the infrared wavelength was used as an internal reference to compensate for leaf thickness (Torres Netto et al., 2005). The

TABLE 1 | Treatments used to evaluate drought response in two potato genotypes.

\begin{tabular}{ll}
\hline Code & Treatments \\
\hline Cr & Perla Negra control \\
C10 & Perla Negra 10 days of drought \\
C15 & Perla Negra 15 days of drought \\
Dr & Diacol control \\
D10 & Diacol 10 days of drought \\
D15 & Diacol 15 days of drought \\
\hline
\end{tabular}

Drought was applied 60 dae. 
leaf area index (LAI) was estimated using an Accupar LP-80 ceptometer (Decagon Devices, USA). Due to semi-erect growth habit of Perla Negra and Diacol Capiro, plants were tutored (45 dae) and separated avoiding overlapping between them. Additionally, the analysis where based on segments involved reducing the error based on clumping effects of a canopy. Similar studies on single plants have estimated LAI in greenhouse under similar conditions. (Mushagalusa et al., 2008; Moeller et al., 2014; Mendoza-Pérez et al., 2017). Finally, three readings per plant were averaged to get the final LAI value. Total water content $\left(\mathrm{H}_{2} \mathrm{Ot}\right)$ was evaluated by difference of dry and fresh mass.

\section{Yield}

Tuber harvest was carried out 130 dae for Perla Negra and 140 dae for Diacol Capiro according to the production cycle of each genotype and following the cultural classification practice used in Colombian productive potato areas. Tubers were then classified into four categories as follows: 1, 2, 3 and "Richie," where large tubers were included in category 1 and the smallest ones were classified as "Richie." The final harvest occurred when plants in each irrigation treatment reached senescence onset. Fresh and dry mass was measured. Stems, leaves and roots were weighted with a digital balance (Ohaus sp4001- USA). These samples were dried at $80^{\circ} \mathrm{C}$ during 3 days. Tubers were cut and dried for $24 \mathrm{~h}$ at $120^{\circ} \mathrm{C}$ and $80^{\circ} \mathrm{C}$ for 3 days.

\section{Canopy Spectral Information}

The reflectance information was captured using of spectroradiometer FieldSpec ${ }^{\circledR} 4$ Hi-Res (ASD Inc., USA) from 350 to 2,500 $\mathrm{nm}$ with interval of $1 \mathrm{~nm}$. A leaf clip was used for nondestructive data collection. The leaf clip and contact probe device reduces interferences, such as atmospheric disturbances (e.g., sunlight) due to a trigger lock/release gripping system and a self-contained light source. The integrated pre-calibrated white reference panel of the ASD leaf clip was used for calibration purposes each 20 measurements (Lehmann et al., 2015). Those were taken $(25,45,56,62,63,67,68,69$, and 107 dae.) on expanded and sun-exposed leaves located in the middle third section of the plant at morning ( $\sim 9$ am). For each plant sampled, six measurements on completely extended leaflets were carried out. Two plants per treatment in each block were evaluated for a total of eight plants per treatment. The spectral signatures and indexes were calculated using custom python script. The indexes were calculated in the spectral region between 526 and $970 \mathrm{~nm}$ (Bowman et al., 2015; Table 2). The visible spectrum ranges from 526 to $780 \mathrm{~nm}$ and the near infrared (NIR) extends from $780 \mathrm{~nm}$ to $970 \mathrm{~nm}$. Those indexes were correlated with sixteen physiological variables measured (LAI, Ci, gs, VPD, A, E, WUE, SPAD, $\mathrm{H}_{2} \mathrm{Ot}$, yield, FA, NAR, RGR, LAR, EAR, and $\mathrm{RGR}_{\mathrm{tub}}$ ).

Growth parameters were calculated according to Hunt (1982): net assimilation rate (NAR), relative growth rate (RGR), leaf area ratio (LAR), economic assimilation rate (EAR) and relative growth rate for tubers $\left(\mathrm{RGR}_{\mathrm{tub}}\right)$. In addition, foliar area (FA) was measured with the CompuEye software (Bakr, 2005) where the leaf area is calculated based on a leaf image of VGA size. Images have background contrasting with that of the leaves. It was marked with two points which length between them was $20 \mathrm{~cm}$.

\section{Statistical Analysis}

The SAS v9.3 software (SAS Institute, Cary, NC, USA) was used to carry out an ANOVA and a GLM (General Lineal Model) procedure, to evaluate the effects of treatments on physiological variables using a Tukey test with repeated measures over time. Significance on statistical tests was assessed at $P<0.05$. The relationship between the reflectance indexes and physiological variables were tested with Pearson's Correlation Coefficients.

\section{RESULTS}

\section{Gas Exchange}

All treatments presented similar levels of photosynthesis $(\sim 10.60$ $\left.\mu \mathrm{mol} \mathrm{CO} \mathrm{CO}_{2} \mathrm{~m}^{-1}\right), \operatorname{VPD}(\sim 1.31 \mathrm{kPa})$, water use efficiency (WUE) $\left(\sim 2.1 \mathrm{mmol} \mathrm{CO} \mathrm{mol}^{-1} \mathrm{H}_{2} \mathrm{O}\right)$ and internal carbon dioxide $\left(\sim 321.79 \mu \mathrm{mol} \mathrm{mol}^{-1}\right)$ without significant differences (Figure 1). However, a reduction in photosynthesis was observed at 70-75 dae. During drought treatments, photosynthesis decreased for C10, C15, D10 and D15 in a ratio of 19, 39, 77 , and $66 \%$, respectively. In addition, treatments under 10 days of drought (70-75 dae) presented the lowest $\mathrm{Ci}$ values (Figure 1D) with decreasing ratios (44 and 50\% for $\mathrm{C} 10$ and D10, respectively). In contrast, $\mathrm{Ci}$ values were higher in Perla Negra under 15 days of drought (3\%) while in Diacol Capiro these decreased to $10 \%$. Similarly, VPD values increased under drought conditions (70-75 dae) for C10 (28\%), C15 (7\%), D10 (66\%), and D15 (41\%) (Figure 1B). Moreover, during drought periods Diacol Capiro's control (Dr) showed the lowest WUE value, whereas plants of both genotypes under 10 days of drought (D10 and C10) presented higher values because the photosynthesis/transpiration relation was greater than in other treatments (Figures 1A, 2B). D10 showed the highest WUE value after a drought period (Figure 1C).

The stomatal conductance had a direct effect on transpiration during water deficit situations. As was expected, there were no significant differences for transpiration (e) and stomatal conductance $\left(g_{s}\right)$ between 35 and 60 dae, because all treatments received the same amount of water. Transpiration displayed maximum values of $\sim 11 \mathrm{mmol} . \mathrm{m}^{-2}$. $\mathrm{s}^{-1}$ in well hydrated plants of the two genotypes tested (Figure 2). However, Diacol Capiro presented a reduced transpiration level under both drought treatments (70-75 dae) for D10 $\left(0.46 \mathrm{mmol} \mathrm{m}^{-2} \mathrm{~s}^{-1}\right)$ and D15 (1.7 mmol m $\left.\mathrm{m}^{-2} \mathrm{~s}^{-1}\right)$. Therefore, Diacol Capiro plants displayed reductions for $\mathrm{D} 10(98 \%)$ and $\mathrm{D} 15(78 \%)$ in relation to its control (Dr). Similarly, stomatal conductance decreased under drought for D10 (98\%) and D15 (93\%). Interestingly, Perla Negra did not show significant differences under water stress conditions, however, at the final stage (95 dae), its transpiration was significantly low (64\%).

\section{Chlorophyll Concentration, Water Content, and Leaf Area Index}

There were significant differences among genotypes, showing Diacol Capiro an average of 41 SPAD and Perla Negra an average 
TABLE 2 | Indexes and formulas derived from reflectance information.

\begin{tabular}{|c|c|c|c|}
\hline \multicolumn{2}{|c|}{ Reflectance index* } & \multirow{2}{*}{$\begin{array}{l}\text { Formula }^{\star *} \\
((\mathrm{R}(900 \mathrm{~nm})-\mathrm{R}(680 \mathrm{~nm})) /(\mathrm{R}(900 \mathrm{~nm})+\mathrm{R}(680 \mathrm{~nm}))\end{array}$} & \multirow{2}{*}{$\begin{array}{l}\text { References } \\
\text { Rouse et al., } 1973\end{array}$} \\
\hline NDVI & Normalized Vegetation Index & & \\
\hline SR & Simple Ratio & $(\mathrm{R}(900 \mathrm{~nm})-(\mathrm{R}(680 \mathrm{~nm}))$ & Jordan, 1969 \\
\hline PRI & Photochemical Reflectance Index & $(\mathrm{R}(531 \mathrm{~nm})-\mathrm{R}(570 \mathrm{~nm})) /(\mathrm{R}(531 \mathrm{~nm})+\mathrm{R}(570 \mathrm{~nm}))$ & Penuelas et al., 1997 \\
\hline PSSRa & Pigment-Specific Simple Ratio of Chl-a & $(\mathrm{R}(800 \mathrm{~nm})) /(\mathrm{R}(680 \mathrm{~nm}))$ & Blackburn, 1999 \\
\hline NWI2 & Normalized Water Index 2 & $(\mathrm{R}(970 \mathrm{~nm})-\mathrm{R}(850 \mathrm{~nm})) /(\mathrm{R}(970 \mathrm{~nm})+\mathrm{R}(850 \mathrm{~nm}))$ & \\
\hline NWI3 & Normalized Water Index 3 & $(\mathrm{R}(970 \mathrm{~nm})-\mathrm{R}(920 \mathrm{~nm})) /(\mathrm{R}(970 \mathrm{~nm})+\mathrm{R}(920 \mathrm{~nm}))$ & \\
\hline NWI4 & Normalized Water Index 4 & $(\mathrm{R}(970 \mathrm{~nm})-\mathrm{R}(880 \mathrm{~nm})) /(\mathrm{R}(970 \mathrm{~nm})+\mathrm{R}(880 \mathrm{~nm}))$ & \\
\hline $\mathrm{ONI}$ & Oryza N Index & $(\mathrm{R}(810 \mathrm{~nm})) /(\mathrm{R}(560 \mathrm{~nm}))$ & Xue et al., 2004 \\
\hline DZNI & Dry Zea N Index & $(\mathrm{R}(575 \mathrm{~nm})) /(\mathrm{R}(526 \mathrm{~nm}))$ & Zhao et al., 2003 \\
\hline
\end{tabular}

The spectral region used ranged between 526 and $970 \mathrm{~nm}$. Chlorophyll's electromagnetic absorption range is between 400 and $500 \mathrm{~nm}$, and from 600 to $700 \mathrm{~nm}$. ${ }^{*}$ Reflectance indexes taken from Bowman et al. (2015).

**R represents the reflectance measured at a particular wavelength.
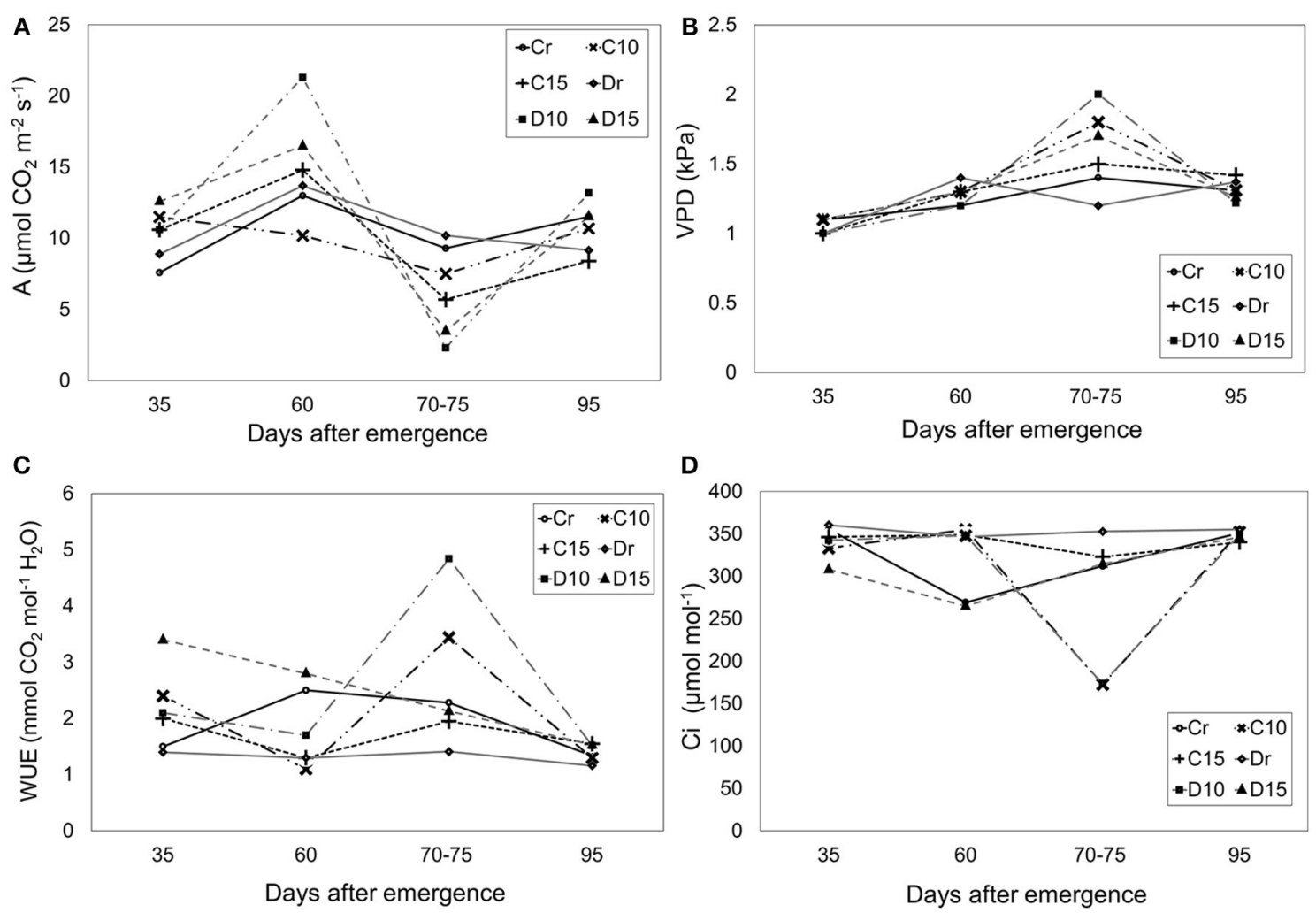

FIGURE 1 | Physiological traits measured under three drought treatments [10 and 15 days without water and a control (r)] in two genotypes: Perla Negra $=$ C and Diacol Capiro = D. Photosynthesis (A), (B) Vapor pressure deficit (VDP), (C) Water use-efficiency (WUE), and (D) Intra cellular carbon dioxide (Ci). Significant difference was found for D10 (VPD) (Dunnett comparison at 0.05).

of only 24 SPAD. Therefore, Diacol Capiro displayed greater chlorophyll content (67\%) than Perla Negra, and in general, the results showed increased chlorophyll content values under water stress conditions (Figure 3). However, there were no significant differences among treatments. Nevertheless, under 10 days of water stress, the chlorophyll value increased for D10 (31\%) and C10 (18\%), compared with their controls (Dr and $\mathrm{Cr}$ ). Interestingly, D15 decreased 2\% and C15 increased 8\% SPAD units (Figure 3A).

The maximum LAI expression was presented at start flowering $(60 \mathrm{dae})$ where Diacol Capiro was 6\% higher than Perla Negra with values of 4.7 and 4.2 , respectively. During 

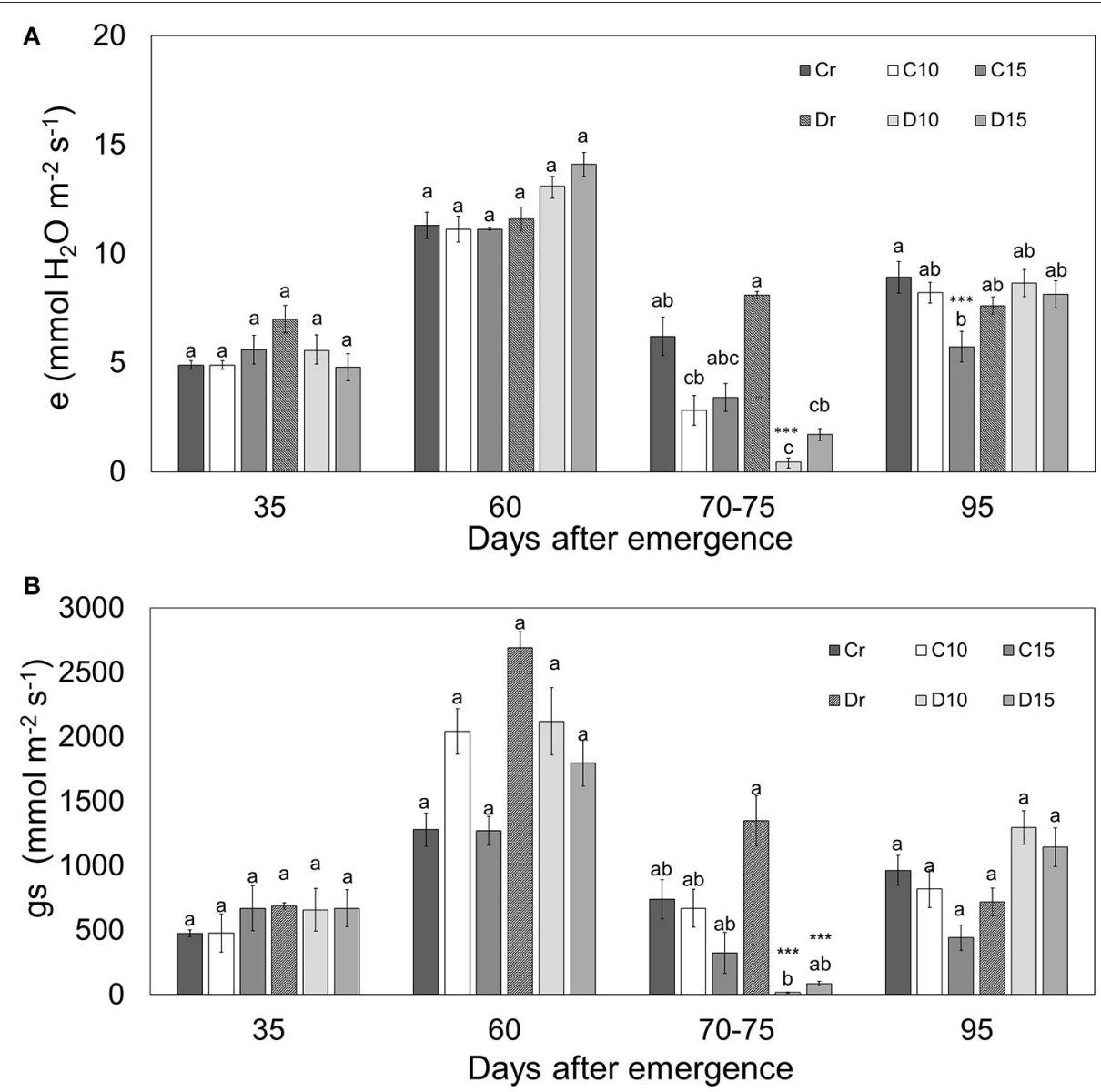

FIGURE 2 | Transpiration (e) (A) and stomatal conductance (gs) (B) in two genotypes (Perla Negra-C and Diacol Capiro-D) under three drought treatments [10 and 15 days without water, and a control $(r)]$. Means with the same letter are not found significantly different by Tukey's test. Dunnett comparisons are significant at $0.05\left({ }^{\star \star \star}\right)$.

drought period (70-75 dae), Diacol Capiro presented a lower leaf area index (LAI) value (4\%) than Perla Negra under normal watering conditions. Plants under drought stress, LAI presented significant differences between treatments. Therefore, the controls (Dr and $\mathrm{Cr}$ ) showed the highest values during drought stress period compared with other treatments that presented a reduced LAI, e.g., D10 (35\%), D15 (62\%), C10 (31\%), and $\mathrm{C} 15$ (52\%). As expected, during the rehydration phase (95 dae), LAI became stable without differences between treatments (Figure 3B).

Diacol Capiro showed higher water content (42\%) than Perla Negra under good watering conditions. However, when plants were submitted to water stress, a significant decrease in total water content was observed (Figure 3C). Particularly, reduction in 47,46 , and 56\% were found for C15, D10 and D15, respectively. Interestingly, $\mathrm{C} 15$ was the treatment that showed the lowest total water content value during and after the drought stage.

\section{Yield}

On average, one well-watered potato plant produced 22 tubers weighing in total $524 \mathrm{~g}$ for Perla Negra and Diacol Capiro produced 15 tubers that weighed $528 \mathrm{~g}$. Considering all treatments, the number of tubers per category did not show significant differences (Figure 4A). However, Perla Negra (Cr) had the highest number of tubers classified in category "richie" showing no significant differences in weight compared with other treatments, which means that the tubers produced were very small. In addition, tuber weight per plant was affected under 15 days of drought for both genotypes, since no tubers obtained could be classified in category 1 (Figure 4B). Similarly, Diacol Capiro's tubers from D15 plants belonging to category 2 were significantly lower (58\%) compared to its watered control (Dr). In contrast, Perla Negra plants C15 presented a slight reduction of $25 \%$ in its yield. Finally, under 15 days of stress both genotypes showed a similar yield reduction, i.e., $47 \%$ in Perla Negra and 48\% in Diacol Capiro. Therefore, under these experimental conditions Perla Negra showed less affectation of its tuber production than Diacol Capiro, and this material has to be further evaluated on field drought trials.

\section{Canopy Spectral Information}

The spectral profiles were plotted showing a clear variation between signatures from 700 to $1,300 \mathrm{~nm}$. Moreover, comparing the spectral signature before (Figure 5A), during (Figure 5B) 

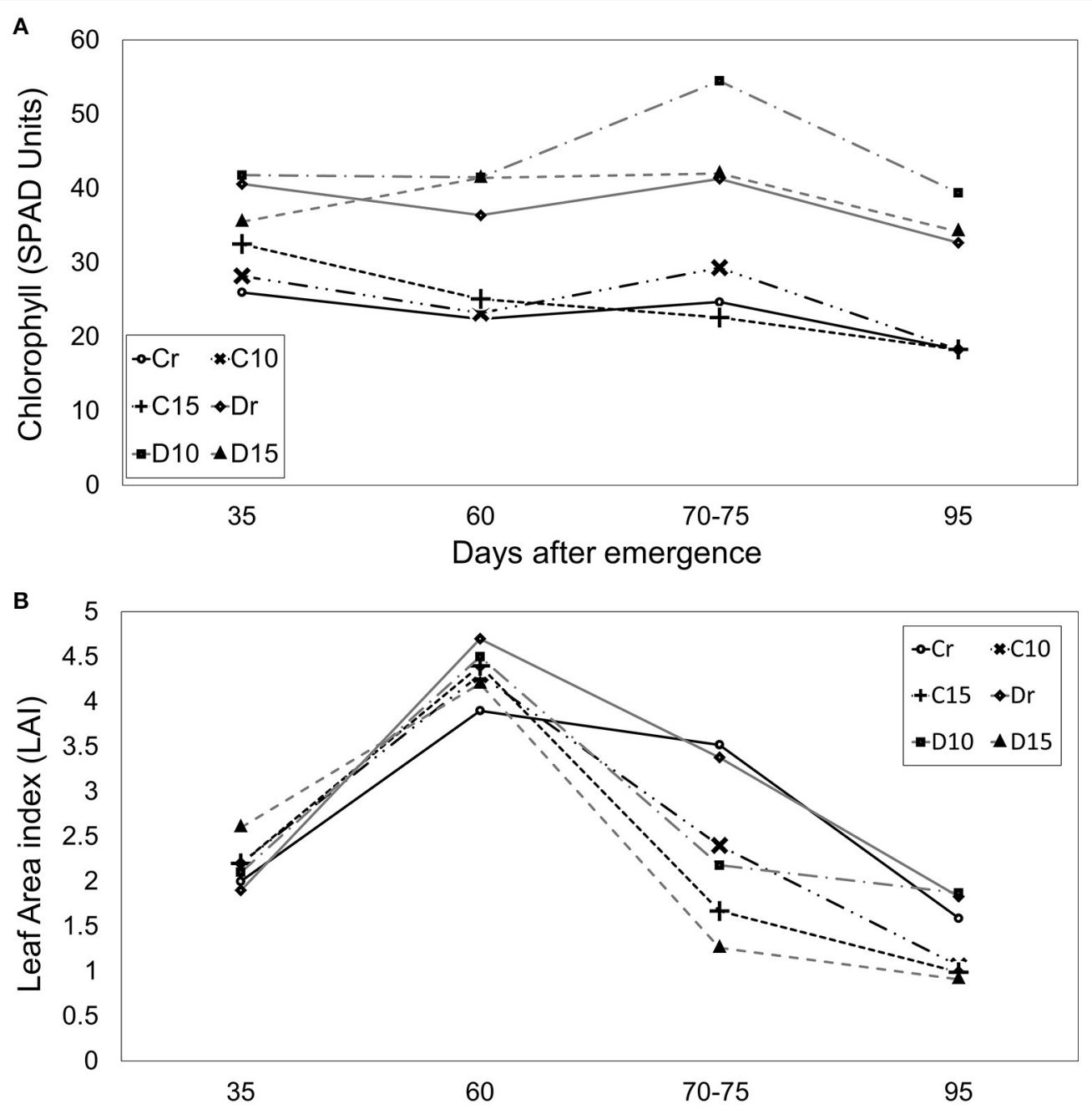

Days after emergence

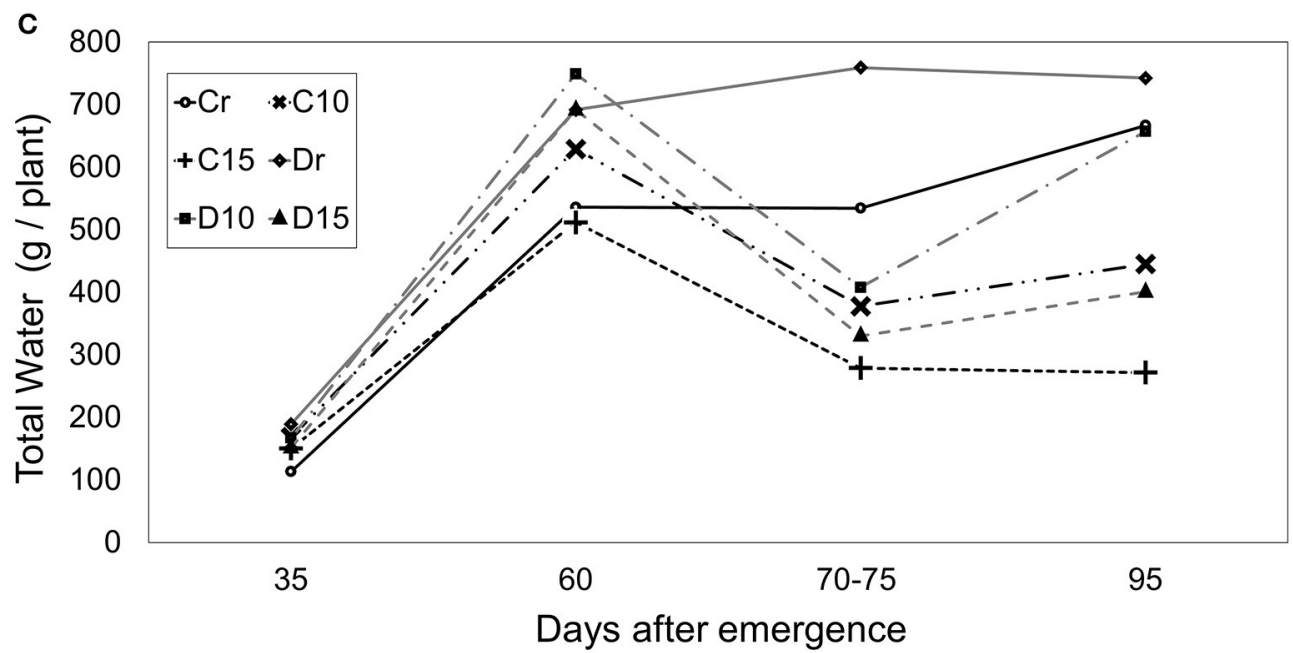

FIGURE 3 | Chlorophyll concentration (A), leaf area index (B) and total water (C) during different crop stages (days after emergence - dae) in two genotypes (Perla Negra $-\mathrm{C}$ and Diacol Capiro-D) under three drought treatments [10 and 15 days without water, and a control (r)]. 

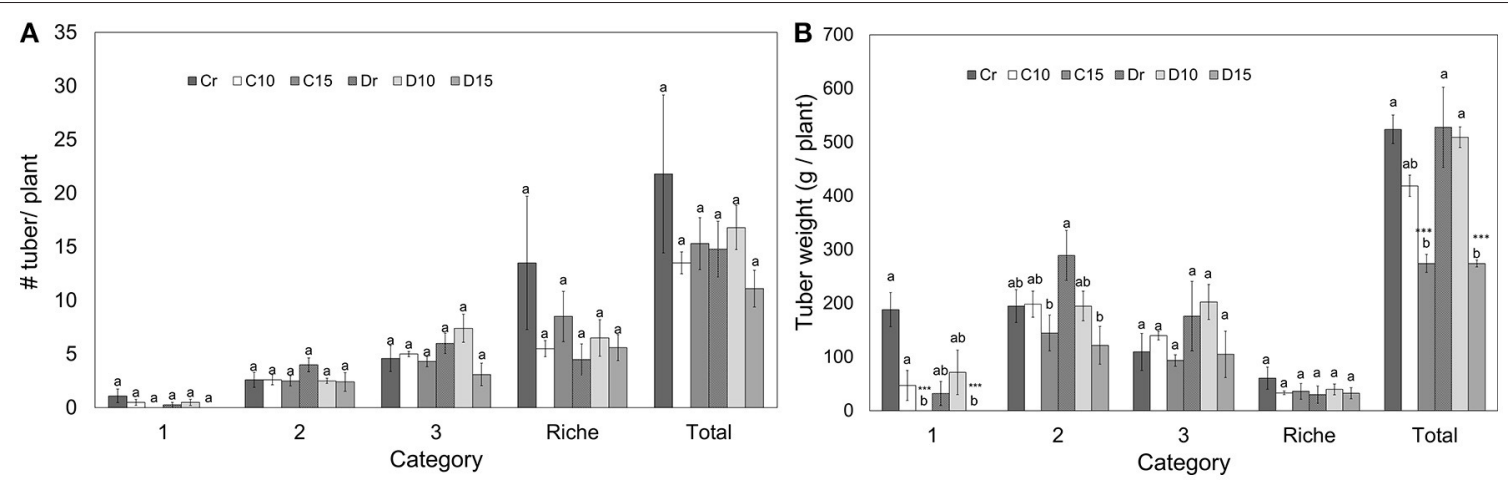

FIGURE 4 | Number of tubers per plant (A) and tuber weight (B) classified into categories that are found in two genotypes (Perla Negra-C and Diacol Capiro-D) under three drought treatments [10 and 15 days without water, and a control (r)]. Tukey means with the same letter are not significantly different. Dunnett comparisons are significant at 0.05
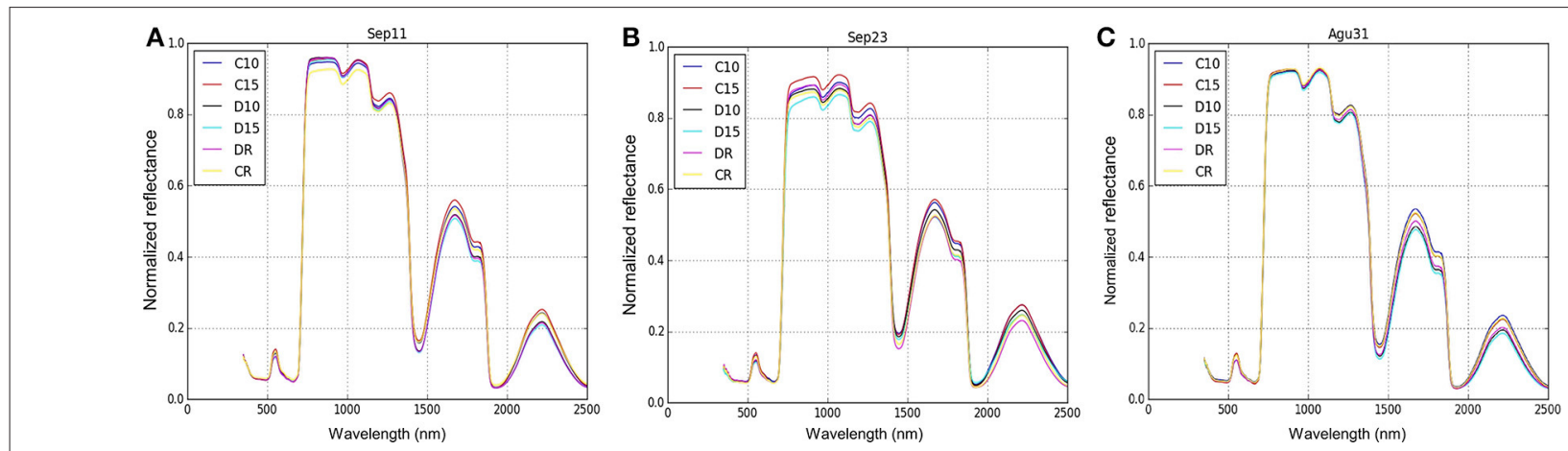

FIGURE 5 | Spectral signature profile of two genotypes (Perla Negra-C and Diacol Capiro-D) under three drought levels. The spectral data were collected in three different periods: before drought (A), 9 days of suffering from drought (B) and after drought-rehydration (C).

and after (Figure 5C) the drought treatment, there was a clear difference between D15 (lowest reflectance) and C15 (highest reflectance).

The results showed that spectral indexes presented correlation with LAI, $\mathrm{H}_{2} \mathrm{Ot}, \mathrm{FA}, \mathrm{LAR}$, and $\mathrm{RGR}_{\mathrm{TUB}}$ (Table 3). Specifically, water indexes (NWI1, NWI2, y NWI4) were negatively correlated with all physiological variables except LAR. In contrast, indexes WI, NDVI, RNDVI, and DZNI showed positive correlation with $\mathrm{H}_{2}$ Ot. In addition, NWI3 was negatively correlated with $\mathrm{H}_{2} \mathrm{Ot}$. Interestingly, half of the reflectance indexes evaluated showed correlation with $\mathrm{RGR}_{\mathrm{TUB}}$, i.e., the plants efficiency to produce dry tuber mass. Also, PRI presented the highest correlation coefficient with RGR $\mathrm{TUB}_{\text {. }}$

\section{DISCUSSION}

\section{Gas Exchange}

In the present study, the photosynthesis (A) decreased during the period of 10 and 15 days of water stress without big differences compared to the watered control. However, Diacol Capiro plants were the most affected under stress conditions. Moreover, similar reduction of internal leaf $\mathrm{CO}_{2}(\mathrm{Ci})$ was found in $\mathrm{C} 10$ and D10. At severe stress states, C15 showed Ci stability compared to the control, while Diacol Capiro maintained its decreasing pattern. This phenomenon is mainly due to photosynthesis decrease resulting from a reduction of internal carbon, where the biochemical capacity for carbon assimilation and utilization is reduced during drought periods (Reddy et al., 2004; Oliver et al., 2009). Thus, decreased Ci confirms the predominance of stomatal limitation in restricting photosynthetic rate in the early water loss phase (Flexas and Medrano, 2002). During stomata closure, the $\mathrm{CO}_{2}$ inside the leaf (Ci) initially declines with increasing stress and then increases as drought becomes more severe (Lawlor, 1995). However, the debate continues as to whether drought mainly limits photosynthesis through stomatal closure or through metabolic impairment (Tezara et al., 1999; Lawson et al., 2003). In fact, under stress conditions that limit $\mathrm{CO}_{2}$ fixation, the rate of production of reducing power is greater than the rate of its use by the Calvin cycle. Protection mechanisms against excess in reducing production power are thus an important strategy under water stress (Reddy et al., 2004). These photoprotective mechanisms compete with photochemistry for the absorbed energy, leading to a decrease in the PSII's quantum yield (Genty et al., 1989). The photosynthesis rate in higher plants depends on the activity of ribulose-1, 5bisphosphate carboxylase/oxygenase (Rubisco) as well as on the synthesis of RuBP (Chaitanya et al., 2002). Decreasing synthesis of Rubisco under drought was evidenced by a rapid decrease in 
TABLE 3 | Pearson's correlation between reflectance indexes and physiological variables.

\begin{tabular}{|c|c|c|c|c|c|c|c|c|c|c|c|c|}
\hline \multirow{2}{*}{$\begin{array}{l}\text { Physiological } \\
\text { variables }\end{array}$} & \multicolumn{12}{|c|}{ Reflectance indexes } \\
\hline & wi & nwi1 & nwi2 & nwi3 & nwi4 & sr & rndvi & ndvi & pri & pssra & oni & dzni \\
\hline \multirow[t]{2}{*}{ LAI } & 0.27921 & -0.62158 & -0.85564 & -0.52771 & -0.71344 & 0.73109 & 0.38956 & 0.37412 & 0.93215 & 0.74756 & 0.62348 & 0.19029 \\
\hline & 0.1864 & 0.0012 & $<0.0001$ & 0.0080 & $<0.0001$ & $<0.0001$ & 0.0599 & 0.0717 & $<0.0001$ & $<0.0001$ & 0.0011 & 0.3731 \\
\hline $\mathrm{H}_{2} \mathrm{Ot}$ & 0.79672 & -0.84996 & -0.66592 & -0.87514 & -0.80409 & 0.63429 & 0.79623 & 0.79566 & 0.52364 & 0.62531 & 0.75680 & 0.77678 \\
\hline & 0.0077 & $<0.0001$ & $<0.0001$ & 0.0001 & $<0.0001$ & $<0.0001$ & 0.0015 & 0.0020 & $<0.0001$ & $<0.0001$ & $<0.0001$ & 0.0238 \\
\hline \multirow[t]{2}{*}{ LAR } & 0.50722 & -0.58176 & -0.73292 & -0.48779 & -0.64847 & 0.89306 & 0.77449 & 0.75307 & 0.86168 & 0.89115 & 0.78420 & 0.12556 \\
\hline & 0.0317 & 0.0113 & 0.0005 & 0.0400 & 0.0036 & $<0.0001$ & 0.0002 & 0.0003 & $<0.0001$ & $<0.0001$ & 0.0001 & 0.6196 \\
\hline \multirow[t]{2}{*}{ RGR $_{\text {tub }}$} & 0.32447 & -0.77680 & -0.88840 & -0.69747 & -0.83101 & 0.81788 & 0.62149 & 0.58668 & 0.91621 & 0.82648 & 0.73310 & -0.06231 \\
\hline & 0.1890 & 0.0001 & $<0.0001$ & 0.0013 & $<0.0001$ & $<0.0001$ & 0.0059 & 0.0105 & $<0.0001$ & $<0.0001$ & 0.0005 & 0.8060 \\
\hline
\end{tabular}

Pearson Correlation Coefficients

Prob $>|r|$ under $\mathrm{HO}:$ Rho $=0$

The significant values are highlighted in bold.

the abundance of small subunits of Rubisco ( $\mathrm{rbcS}$ ) in tomato (Vu et al., 1999). Finally, our results were consistent with the general findings of Vos and Haverkort (2007) where the net photosynthesis of potatoes is not easily affected by drought stress and may only be affected under severe water stresses.

The VPD of the atmosphere can negatively affect plant growth as plants reduce stomatal conductance for water vapor $\left(g_{w v}\right)$ in response to increasing VPD, limiting the ability of plants to assimilate carbon (Ocheltree et al., 2013). In our study, the greatest variations were viewed for Diacol Capiro with (Figure 1) and Perla Negra showed a more stable VPD. Similar results were presented by Silva et al. (2013), where the intensification of VPD is related directly with higher stomatal closure and correlated with photosynthesis reduction. Therefore, a change of VPD on the net assimilation rate indicates a direct effect of VPD on stomata (James et al., 1983). High VPD may decrease photosynthetic performance due to stomatal (diffusion) and nonstomatal (mesophyll) limitations (Shibuya et al., 2016). Most plants show a nonlinear, asymptotic transpiration (E) response to increasing VPD, but some plants show a reduction in $\mathrm{E}$ as VPD continues to increase, which has been referred to as an "apparent feedforward" response (Monteith, 1995). The stomatal conductance sensitivity to VPD is a key regulator of water use and carbon assimilation strategies in plants (Ocheltree et al., 2013).

The increasing worldwide water resources shortage requires irrigation management optimization in order to improve water use efficiency (WUE) (Liu et al., 2006). In our study, the WUE increased with decreasing irrigation amount with values of $4.84 \mathrm{mmol} \mathrm{CO}_{2} \mathrm{~mol}^{-1} \mathrm{H}_{2} \mathrm{O}$ that is consistent with previous studies of WUE in potato (Vos and Groenwold, 1989; Trebejo and Midmore, 1990; Onder et al., 2005; Fleisher et al., 2008). WUE has been known to increase with increasing drought stress and reduced water supply (Meyers et al., 1984). However, superior water-use efficiency (WUE) is not synonymous with drought resistance and high yield under drought stress (Blum, 2009). Moreover, drought tolerance was found to be associated with low WUE when analyzed by delta (carbon isotope discrimination $\mathrm{C} 12 / \mathrm{C} 13$ ) under limited water supply (Solomon and Labuschagne, 2004). For instance, our results suggested that Perla Negra could be drought resistant because its WUE values were lower than the ones of Diacol Capiro under water stress conditions. Similarly, Pinheiro et al. (2005) found that a drought resistant Coffea canephora clone had relatively low WUE. Nevertheless, further studies using Perla Negra under severe water deficit on field, including soil management practices (e.g., plant nutrition) are necessary.

Under water stress conditions Diacol Capiro presented a reduced stomatal conductance $\left(\mathrm{g}_{\mathrm{s}}\right)$ and transpiration $(e)$. Similar results were reported by Fleisher et al. (2008) where transpiration rates were lower for plants grown under water stress treatments. Interestingly, Perla Negra did not show significant differences for $\mathrm{g}_{\mathrm{s}}$ or $e$. During drought stress, stomatal closure inhibits transpiration more than it decreases intercellular $\mathrm{CO}_{2}$ concentrations (Taiz and Zeiger, 2002), helping to conserve water and maintaining an adequate leaf water status, but at the same time, reducing $g_{s}$ concentrations (Chaves et al., 2002). Furthermore, the stomatal conductance began to have a greater effect on transpiration than the VPD (leaf-air) during water deficit (Silva et al., 2013).

Drought stress progressively decreases $\mathrm{CO}_{2}$ assimilation rates due to reduced stomatal conductance. A good correlation between leaf water potential and stomatal conductance always exists, and it should be taken as an integrative parameter to assess photosynthetic rate, even under drought stress (Reddy et al., 2004). In contrast, negative correlation has been found with $\mathrm{g}_{\mathrm{s}}$ and $e$ compared with WUE (Blum, 2009). Therefore, genotypes that produce the same amount of photoassimilates while their $e$ decreases could potentially be drought tolerant materials. Consequently, it is possible to enhance drought tolerance by reducing transpiration (Bañon et al., 2006). As long as the biochemical pathways of photosynthesis continue to be (apparently) unresponsive to conventional breeding schemes, genotypic transpiration efficiency and WUE are mainly driven by plant traits that reduce transpiration and crop water-use, 
processes which are of utmost importance for plant production (Blum, 2009).

\section{Chlorophyll Concentration, Water Content, and Leaf Area Index}

Under water stress conditions the chloroplast concentration increases due to loss of turgor and the chlorophyll's photochemical activity is reduced (Genc et al., 2013). However, chlorophyll content also depends on the growth stage. In fact, our results reported a decreasing behavior during the final phase (95 dae) and seen by finding chlorotic leaves during the harvest phase (Palaniswami and Peter, 2008). Similarly, this was observed in maize where chlorophyll readings decrease as the plant approaches maturity (Genc et al., 2013). In addition, our results showed that leaf area decreased under water stress causing chlorophyll concentration increases in plants submitted to slight water deficit. These results agree with those obtained by Teixeira and Pereira (2007), where leaf chlorophyll content increased significantly in response to drought (5.6\%). According to Deblonde and Ledent (2001), the LAI reduction can affect the production of photoassimilates, dry matter and also tuber yield. Therefore, LAI is used to predict primary photosynthetic production, evapotranspiration and also as a reference tool for crop growth. Similar values of LAI in potato under greenhouse were found by Flores-López et al. $(2016 \mathrm{a}, \mathrm{b})$ These results showed that Perla Negra is more photosynthetic efficient than Diacol Capiro because even though it had a lower LAI value at 60 dae, it has a greater yield that Diacol Capiro.

On the other hand, potato responds to drought stress with epinasty or with the leaves showing a downward curvature. Unlike wilting, epinasty does not involve turgor loss (Taiz and Zeiger, 2002). Epinasty avoids losing water when the leaf area and the leaf area index decreases. When potato plants suffer longer drought periods their leaves drop, and this is followed by wilting that starts from the lower strata leaves. Nevertheless, if leaves have some greenness, potato plants will recover turgor and finalize their production cycle. As expected in this study, the water content and LAI decreased proportionally to the severity of the drought stress on the genotypes assessed. Total water content of D10 and C10 had lower water content than the control plants, but $\mathrm{C} 15$ and D15 showed the lowest values during water stress periods (70 and 75 dae). Water tissue content affects physiological processes as stomatal conductance in several plant species under drought conditions; this is most probably due to increased sensitivity to xylem-carried ABA which is induced by low leaf water potentials (Wilkinson and Davies, 2002).

\section{Yield}

In this study, low water availability affected tuber yield. This is one of the most important variables to evaluate drought tolerance in potato plants, and it is very well known that under field conditions, drought causes drastic losses in potato tuber yield and/or quality (Deblonde and Ledent, 2001; Walworth and Carling, 2002; Stark et al., 2013). Consequently, drought evaluation is based on a combination of yield stability and high relative yield under water deficits (Obidiegwu et al., 2015). The magnitude of the drought effects on potato production depends on the phenological timing, duration, and severity of the stress (Schafleitner, 2009). For instance, Dalla-Costa et al. (1997) showed that tuber yield reduction under stress treatments was almost proportional to biomass decrease, and was a result of reduced leaf area and less photosynthesis per leaf area unit. For this reason, water use efficiency is calculated as the proportion of fresh tuber yield and the water content applied (Trebejo and Midmore, 1990).

Our results suggest that yield reduction under water stress can be caused by reduced leaf area and/or reduced photosynthesis per leaf area unit. Therefore, facing the current climate change scenario, these parameters have to be considered on every potato breeding program where ideally all potato cultivars should be drought tolerant with a high yield potential under drought stress (Soltys-Kalina et al., 2016).

\section{Canopy Spectral Information}

Five physiological variables were correlated with spectral indexes. Specifically, some vegetative and photochemical indexes (SR, PRI, PSSRa) were positively correlated with mayor physiological variables, except $\mathrm{H}_{2} \mathrm{Ot}$. Previously, these indexes have been reported as biomass indicators (Babar et al., 2006a). Likewise, water indexes or indexes using the $970 \mathrm{~nm}$ wavelength (minor water absorption band) have been used as plant water status indicators (Bowman et al., 2015). The spectral data showed that reflectance at water sensitive wavebands (940-970 $\mathrm{nm}$ ) before irrigation was slightly higher than after irrigation. Similar results were reported by Genc et al. (2013) evaluating spectral reflectance of sweet corn under water stress. Reflectance properties of plants depend in part on the amount of water stored in the leaf cells, in particular in the near infrared (NIR) region (Rodríguez-Pérez et al., 2007; Govender et al., 2009). Crop yield is based on a complex interaction of different agronomic factors such as density, vigor, maturity and stress resistance that altogether, can be used as yield indicators. However, the spectral reflectance of the crop is dependent on the phenology, stage type and crop health. For instance, early prediction of potato yield using multispectral images was reported by Al-Gaadi et al. (2016). Their results suggest that the PRI index will be a useful parameter to predict yield.Similarly, the $\mathrm{PRI}_{512}$ index has been reported as an indicator of water stress (Hernández-Clemente et al., 2011). In addition, reflectance measured before irrigation was generally higher than after irrigation in the NIR region, and a similar reflectance behavior under water stress was found in corn plants (Genc et al., 2013).

A spectral model in the form of a normalized difference index was identified as an example for nondestructive estimation of RWC (Zygielbaum, 2009). This suggests that spectral information will be a useful tool to predicting yield in potato, including plants under water stress. Previous studies on wheat presented correlation between vegetative and photochemical related indexes with biomass production and yield (Babar et al., 2006b; Prasad et al., 2007; Gutierrez et al., 2010; Bowman et al., 2015). In our study, SR, PRI, and PSSRa had correlation with biomass production and LAI, LAR, FA and RGRtub; RNDVI, NDVI were correlated with total water content. Hence, the use of spectral indexes could be useful to get physiological indicators without using destructive sampling. Thus, spectral reflectance is a potential high-throughput method for assessing abiotic and 
biotic stresses in potato. However, further studies have to be done to standardize indexes and prediction models to determine water stress on field trials.

\section{CONCLUSION}

Based on physiological evaluations, Perla Negra was less affected under water stress conditions than Diacol Capiro. Therefore, Perla Negra's photoassimilate production was constant even though plants were under drought stress. Interestingly, during the hydration phase to field capacity, transpiration of $\mathrm{C} 15$ was significantly low, and it may have been caused by a senescence growing cycle that is shorter than the one in Diacol Capiro. This drought tolerant genotype has to be evaluated at population level (half-sib) to evaluate heritability and possible breeding gain within our breeding program.

These results confirm the potential use of spectral reflectance indexes on general plant phenotyping and particularly regarding drought tolerance. These indexes will be useful to accelerate the screening of genebank germplasm to select the putative drought tolerant parents and select the segregant population within a breeding program. The goal is to evaluate a diverse set of germplasm in multienvironmental trials to elucidate the relationship between drought response and genotype $\times$ environment interactions. Additionally, the Colombian potato germplasm bank has been characterized with high-dense SNP array (Berdugo et al., 2017). Therefore, the spectral data and genotyped diversity panel will provide information about loci involved on stress tolerance, and moreover, using genomic

\section{REFERENCES}

Ahmad, F. (2012). Spectral vegetation indexes performance evaluated for Cholistan Desert. J. Geography Reg. Plann. 5, 165-172. doi: $10.5897 /$ JGRP11.098

Ahmadi, S., Andersen, M. N., Plauborg, F., and Poulsen, R. (2010). Effects of irrigation strategies and soils on field-grown potatoes: gas exchange and xylem ABA. Agr. Water Manage. 97, 1486-1494. doi: 10.1016/j.agwat.2010.05.002

Al-Gaadi, A., Hassaballa, A., Tola, E., Kayad, A., Madugundu, R., Alblewi, B., et al. (2016). Prediction of potato crop yield using precision agriculture techniques. PLoS ONE 11:e0162219. doi: 10.1371/journal.pone.0162219

Aparicio, N., Villegas, D., Casadesus, J., Araus, L., and Royo, C. (1999). Spectral vegetation indexes as nondestructive tools for determining durum wheat yield. Agron. J. 92, 83-91. doi: 10.2134/agronj2000.92183x

Babar, A., Reynolds, M., Van Ginkel, M., Klatt, R., Raun, R., and Stone, L. (2006a). Spectral reflectance indexes as a potential indirect selection criteria for wheat yield under irrigation. Crop Sci. 46, 578. doi: 10.2135/cropsci2005.0059

Babar, A., Reynolds, M., Van Ginkel, M., Klatt, R., Raun, R., and Stone, M. (2006b). Spectral reflectance to estimate genetic variation for in-season biomass, leaf chlorophyll, and canopy temperature in wheat. Crop Sci. 46, 1046. doi: $10.2135 /$ cropsci2005.0211

Bakr, E. M. (2005). A new software for measuring leaf area, and area damaged by Tetranychus urticae Koch. J. Appl. Entomol. 129, 173-175. doi: 10.1111/j.1439-0418.2005.00948.x

Bañon, S., Ochoa, J., Franco, A., Alarcón, J., and Sánchez-Blanco, M. J. (2006). Hardening of oleander seedlings by deficit irrigation and low air humidity. Environ. Exp. Bot. 56, 36-43. doi: 10.1016/j.envexpbot.2004.12.004

Baracaldo, A., Carvajal, R., Romero, A. P., Prieto, A. M., García, J., Fischer, G., et al. (2014). Waterlogging affects the growth and biomass production of chonto tomatoes (Solanum lycopersicum L.), cultivated under shading. Rev. Colomb. Cienc. Hortic. 8, 92-102. Available online at: http://www.scielo.org.co/scielo. php?script=sci_arttext\&pid=S2011-21732014000100009 selection models the best genotypes with the highest genomic estimated breeding values (GEBV) can be predicted (Desta and Ortiz, 2014); this will altogether provide valuable tools for potato breeding programs.

\section{AUTHOR CONTRIBUTIONS}

$\mathrm{CG}, \mathrm{RV}$, and AA conceived and conducted the trials. AR assisted in the data collection. CG, AA, and AR were primarily responsible for writing the manuscript.

\section{FUNDING}

Funding for this project was generously provided by Corporación Colombiana de Investigación Agropecuaria (Corpoica), and the Colombian Ministry of Agriculture and Rural Development.

\section{ACKNOWLEDGMENTS}

The authors wish to thank Elsa Romero for her dedication during and beyond the operative work in the greenhouse phase and Diego Sanchez Vivas for his cooperation and patient making figures and correct them each time with right features for this publication. We are also grateful to the Colombian Germplasm Bank for providing the necessary accessions used in this study from the Colombian Core Collection (CCC) of potato. In addition, we wish to thank the Editor and Reviewers for their very helpful input and suggestions.

Basu, P., Sharma, A., Garg, I., and Sukumaran, N. (1999). Tuber sink modifies photosynthetic response in potato under water stress. Environ. Exp. Bot. 42, 25-39. doi: 10.1016/S0098-8472(99)00017-9

Berdugo, C. J., Valbuena, R. I., Sánchez, B. E., Barrero, L. S., and Yockteng, R. (2017). Genetic diversity and association mapping in the colombian central collection of Solanum tuberosum L. Andigenum group using SNPs markers. PLoS ONE 12:e0173039. doi: 10.1371/journal.pone.0173039

Blackburn, G. A. (1999). Relationships between spectral reflectance and pigment concentrations in stacks of deciduous broadleaves. Remote Sens. Environ. 70, 224-237. doi: 10.1016/S0034-4257(99)00048-6

Blum, A. (2009). Effective use of water (EUW) and not water-use efficiency (WUE) is the target of crop yield improvement under drought stress. Field Crops Res. 112, 119-123. doi: 10.1016/j.fcr.2009.03.009

Booij, R., and Uenk, D. F. (2004). "Crop reflection based DSS for supplemental nitrogen dressings in potato production," in Decision Support Systems in Potato Production: Bringing Models to Practice, eds D. K. L. MacKerron and A. J. Haverkort (Wageningen: Wageningen Academic Publishers), 46-53.

Bouman, B. A., Uenk, D., and Haverkort, A. J. (1992). The estimation of ground cover of potato by reflectance measurements. Potato Res. 35, 111-125. doi: $10.1007 / \mathrm{BF} 02357604$

Bowen, T. R., Hopkins, B. G., Ellsworth, J. W., Cook, A. G., and Funk, S. A. (2005). "In-season variable rate $\mathrm{n}$ in potato and barley production using optical sensing instrumentation," in Western Nutrient Management Conference - 2005 Proceedings, Vol. 6 (Salt Lake City).

Bowman, B. C., Chen, J., Zhang, J., Wheeler, J., Wang, Y., Zhao, W., et al. (2015). Evaluating grain yield in spring wheat with canopy spectral reflectance. Crop Sci. 55, 1881-1890. doi: 10.2135/cropsci2014.08.0533

Campbell, P. K. E., Middleton, E. M., McMurtrey, J. E., Corp, L. A., and Chappelle, E. W. (2007). Assessment of vegetation stress using reflectance or fluorescence measurements. J. Environ. Qual. 36, 832-845. doi: 10.2134/jeq2005.0396

Ceccato, P., Flasse, S., Tarantola, S., Jacquemoud, S., and Grégoire, J. M. (2001). Detecting vegetation leaf water content using reflectance in the 
optical domain. Remote Sens. Environ. 77, 22-33. doi: 10.1016/S0034-4257(01) 00191-2

Chaitanya, V., Sundar, D., Masilamani, S., and Reddy, A. (2002). Variation in heat stress-induced antioxidant enzyme activities among three mulberry cultivars. Plant Gowth Regul. 36, 175-180. doi: 10.1023/A:1015092628374

Chalker-Scott, L. (1999). Environmental significance of anthocyanins in plant stress responses. Photochem. Photobiol. 70, 1-9. doi: 10.1111/j.1751-1097. 1999.tb01944.x

Chaves, M., Pereira, S., Maroco, J., Rodrigues, L., Ricardo, P., and Osorio, L. (2002). How plants cope with water stress in the field. Photosynthesis Growth. Ann. Bot. 89, 907-916. doi: 10.1093/aob/mcf105

Clay, D. E., Chang, K. K. G., Clay, S. A., and Dalsted, K. (2006). Characterizing water and nitrogen stress in corn using remote sensing. Agron. J. 98, 579-587. doi: 10.2134/agronj2005.0204

Coleman, W. K. (2008). Evaluation of wild Solanum species for drought resistance. Environ. Exp. Bot. 62, 221-230. doi: 10.1016/j.envexpbot.2007.08.007

Coops, C., Hilker, T., Hall, G., Nichol, J., and Drolet, G. (2010). Estimation of lightuse efficiency of terrestrial ecosystem from space: a status report. Bioscience 60, 788-797. doi: 10.1525/bio.2010.60.10.5

Dalla-Costa, L., Vedove-delle, G., Gianquinto, G., Giovanardi, R., and Peressotti, A. (1997). Yield, water use efficiency and nitrogen uptake in potato: influence of drought stress. Potato Res. 40, 19-34. doi: 10.1007/BF02407559

Dammer, K. H., Dworak, V., and Selbeck, J. (2016). On-the-go phenotyping in field potatoes using camera vision. Potato Res. 59,113-127. doi: 10.1007/s11540-016-9315-y,

DANE-ENEA (2014). Encuesta Nacional Agropecuaria ENA 2014. Bogota: DANEENEA.

Deblonde, P., and Ledent, J. (2001). Effects of moderate drought conditions on green leaf number, stem height, leaf length and tuber yield of potato cultivars. Eur. J. Agron. 14, 31-41. doi: 10.1016/S1161-0301(00)00081-2

Desta, Z. A., and Ortiz, R. (2014). Genomic selection: genome-wide prediction in plant improvement. Trends Plant Sci. 19, 592-601. doi: 10.1016/j.tplants.2014.05.006

Elbatawi, I. E., Ebaid, M. T., and Hemeda, B. E. (2008). Determination of potato water content using nir diffuse reflection method. Misr J. Ag. Eng. 25, 1279-1292. doi: 10.1080/01431161.2011.599346

FAO (2011). Food and Agricultural Organization of the United Nations Database. Rome.

Fleisher, D., Timlin, D., and Reddy, V. (2008). Elevated carbon dioxide and water stress effects on potato canopy gas exchange, water use, and productivity. Agr. Forest Meteorol. 148, 1109-1122. doi: 10.1016/j.agrformet.2008.02.007

Flexas, J., and Medrano, H. (2002). Drought-inhibition of photosynthesis in C3 plants: stomatal and non-stomatal limitations revisited. Ann. Bot. 89, 183-189. doi: $10.1093 / \mathrm{aob} / \mathrm{mcf027}$

Flores-López, R., Martínez Gutiérrez, R., López Delgado, H., and Marín Casimiro, M. (2016b). Periodic application of low concentrations of paclobutrazol and salicylic acid in potatoes in greenhouse. Revista Mexicana de Ciencias Agrícolas 7, 1143-1154. Available online at: http://www.redalyc.org/pdf/2631/ 263146723013.pdf

Flores-López, R., Sotelo Ruiz, E., Rubio Cobarrubias, O., Álvarez-Gonzalez, A., and Marín Casimiro, M. (2016a). NPK levels for the production of potato minitubers in greenhouse in the Toluca Valley. Revista Mexicana de Ciencias Agrícolas 7, 1131-1142. Available online at: http://www.redalyc.org/articulo.oa? id $=263146723013$

Genc, L., Inalpulat, M., Kizil, U., Mirick, M., Smith, S., and Mendes, M. (2013). Determination of water stress with spectral reflectance on sweet corn (Zea mays L.) using classification tree (CT) analysis. Zemdirbyste-Agric. 100, 81-90. doi: 10.13080/z-a.2013.100.011

Genty, B., Briantais, J. M., and Baker, N. R. (1989). The relationship between the quantum yield of photosynthetic electron-transport and quenching of chlorophyll fluorescence. Biochim. Biophys. Acta 990, 87-92. doi: 10.1016/S0304-4165(89)80016-9

Govender, M., Dye, P., Weiersbye, I., Witkowski, F., and Ahmed, F. (2009). Review of commonly used remote sensing and ground-based technologies to measure plant water stress. Water SA 35, 741-752. doi: 10.4314/wsa.v35i5.49201

Gutierrez, M., Reynolds, P., Raun, R., Stone, L., and Klatt, R. (2010). Spectral water indexes for assessing yield in elite bread wheat genotypes under well-irrigated, water-stressed, and high-temperature conditions. Crop Sci. 50, 197-214. doi: 10.2135/cropsci2009.07.0381
Hernández-Clemente, R., Navarro, R., Suárez, L., Morales, F., and Zarco, P. (2011). Assessing structural effects on PRI for stress detection in conifer forests. Remote Sens. Environ. 115, 2360-2375. doi: 10.1016/j.rse.2011.04.036

Hunt, R. (1982). Plant Growth Curves: The Functional Approach to Plant Growth Analysis. London: Edward Arnold.

James, I., Morison, L., and Gifford, M. (1983). Stomatal sensitivity to carbon dioxide and humidity. a comparison of two C3 and two C4 grass species. Plant Physiol. 71, 789-796. doi: 10.1104/pp.71.4.789

Jones, G., and Corlett, E. (1992). Current topics in drought physiology. J. Agric. Sci. 119, 291-296. doi: 10.1017/S0021859600012144

Jordan, F. (1969). Derivation of leaf-area index from quality of light on the forest floor. Ecology 50, 663-666. doi: 10.2307/1936256

Kokaly, R., Despain, D., Clark, R., and Livo, K. (2003). Mapping vegetation in Yellowstone National Park using spectral feature analysis of AVIRIS data. Remote Sens. Environ. 84, 437-456. doi: 10.1016/S0034-4257(02)00133-5

Lawlor, W. (1995). "The effects of water deficit on photosynthesis," in Environment and Plant Metabolism, Flexibility and Acclimation, ed N. Smirnoff (Oxford: BIOS Scientific Publishers), 129-160.

Lawson, T., Oxborough, K., Morison, J., and Baker, N. R. (2003). The responses of guard and mesophyll cell photosynthesis to $\mathrm{CO}_{2}, \mathrm{O}_{2}$, light, and water stress in a range of species are similar. J. Exp. Bot. 54, 1743-1752. doi: 10.1093/jxb/erg186

Lehmann, J., Stoltenberg, A., Römer, M., and Oldeland, J. (2015). Field spectroscopy in the VNIR-SWIR region to discriminate between mediterranean native plants and exotic-invasive shrubs based on leaf tannin content. Remote Sens. 7, 1225-1241. doi: 10.3390/rs70201225

Liu, A., Shahnazari, A., Andersen, M., Jacobsen, S.-E., and Jensen, C. R. (2006). Effects of deficit irrigation (DI) and partial root drying (PRD) on gas exchange, biomass partitioning, and water use efficiency in potato. Sci. Hortic-Amsterdam 109, 113-117. doi: 10.1016/j.scienta.2006.04.004

Mateus, J. (2010). Efecto del ambiente sobre la producción de minitubérculos de 10 genotipos de papa cultivados bajo un sistema aeropónico. Magister Scientiae Thesis, Lima, Universidad Nacional Agraria La Molina.

Mendoza-Pérez, C., Ramírez-Ayala, C., Ojeda-Bustamante, W., and FloresMagdaleno, H. (2017). Estimation of leaf area index and yield of greenhouse-grown poblano pepper. Ingen. Agríc. Biosist. 9, 37-50. doi: 10.5154/r.inagbi.2017.04.009

Meyers, R., Foale, M., and Done, A. (1984). Response of grain sorghum to varying irrigation frequency in the Ord irrigation area. II. Evapotranspiration water-use efficiency. J. Agric. Res. 35, 31-42. doi: 10.1071/AR9840031

Milton, J., Schaepman, E., Anderson, K., Kneubühler, M., and Fox, N. (2007). Progress in field spectroscopy. Remote Sens. Environ. 113, S92-S109. doi: 10.1016/j.rse.2007.08.001

Moeller, C., Evers, J., and Rebetzke, G. (2014). Canopy architectural and physiological characterization of near-isogenic wheat lines differing in the tiller inhibition gene tin. Front. Plant Sci. 5:617. doi: 10.3389/fpls.2014.00617

Monteith, L. (1995). A reinterpretation of stomatal responses to humidity. Plant Cell Environ. 18, 357-364. doi: 10.1111/j.1365-3040.1995.tb00371.x

Mushagalusa, G., ois Ledent, J., and Draye, X. (2008). Shoot and root competition in potato/maize intercropping: effects on growth and yield. Environ. Exp. Bot. 64, 180-188. doi: 10.1016/j.envexpbot.2008.05.008

Nijland, W., de Jong, R., de Jong, S. M., Wulder, M. A., and Bater, C. W. (2014). Monitoring plant condition and phenology using infrared sensitive consumer grade digital cameras. Coops NC. Agr. Forest Meteorol. 184, 98-106. doi: 10.1016/j.agrformet.2013.09.007

Obidiegwu, J., Bryan, G., Jones, G., and Prashar, A. (2015). Coping with drought: stress and adaptive responses in potato and perspectives for improvement. Front. Plant Sci. 6:542. doi: 10.3389/fpls.2015.00542

Ocheltree, T., Nippert, B., and Prasad, P. (2013). Stomatal responses to changes in vapor pressure deficit reflect tissue-specific differences in hydraulic conductance. Plant Cell Environ. 37, 132-139. doi: 10.1111/pce.12137

Oliver, R. J., Finch, J. W., and Taylor, G. (2009). Second generation bioenergy crops and climate change: a review of the effects of elevated atmospheric $\mathrm{CO}_{2}$ and drought on water use and the implications for yield. GCB Bioenergy 1, 97-114. doi: 10.1111/j.1757-1707.2009.01011.x

Onder, S., Caliskan, E., Onder, D., and Caliskan, S. (2005). Different irrigation methods and water stress effects on potato yield and yield components. Agric. Water Manage. 73, 73-86. doi: 10.1016/j.agwat.2004.09.023

Padilla, F., González-Dugo, M., Gavilán, P., and Domínguez, J. (2011). Integration of vegetation indexes into a water balance model to estimate 
evapotranspiration of wheat and corn. Hydrol. Earth Syst. Sci. 15, 1213-1225. doi: 10.5194/hess-15-1213-2011

Palaniswami, M., and Peter, K. V. (2008). Tuber and root crops. Hortic. Sci. Ser. 9, 167.

Penuelas, J., Filella, I., Biel, C., Serrano, L., and Savé R. (1993). The reflectance at the 950-970 $\mathrm{nm}$ region as an indicator of plant water status. Int. J. Remote Sens. 14, 1887-1905. doi: 10.1080/01431169308954010

Penuelas, J., Llusia, J., Pinol, J., and Filella, I. (1997). Photochemical reflectance index and leaf photosynthetic radiation-use-efficiency assessment in Mediterranean trees. Int. J. Remote Sens. 18, 2863-2868. doi: 10.1080/014311697217387

Pilon, R., Klumpp, K., Carrere, P., and Picon-Cochard, C. (2010). Determination of aboveground net primary productivity and plant traits in grasslands with near-infrared reflectance spectroscopy. Ecosystems 13, 851-859. doi: 10.1007/s10021-010-9359-9

Pinheiro, A., Damatta, M., Chaves, M., and Loureiro, M. (2005). Drought tolerance is associated with rooting depth and stomatal control of water use in clones of Coffea canephora. Ann. Bot. 96, 101-108. doi: 10.1093/aob/mci154

Prasad, B., Carver, B. F., Stone, M. L., Babar, M. A., Raun, W. R., and Klatt, A. R. (2007). Potential use of spectral reflectance indexes as a selection tool for grain yield in winter wheat under great plains conditions. Crop Sci. 47, 1426-1440. doi: 10.2135/cropsci2006.07.0492

Raun, W., Solie, J., and Johnson, G. (2001). In-season prediction of potential grain yield in winter wheat using canopy reflctance. Agron. J. 93:131. doi: 10.2134/agronj2001.931131x

Reddy, A., Chaitanya, K., and Vivekanandan, M. (2004). Drought induced responses of photosynthesis and antioxidant metabolism in higher plants. J. Plant Physiol. 161, 1189-1202. doi: 10.1016/j.jplph.2004.01.013

Rodríguez-Pérez, J., Riaño, D., Carlisle, E., Ustin, S., and Smart, D. (2007). Evaluation of hyperspectral reflectance indexes to detect grapevine water status in vineyards. Am. J. Enol. Viticult. 58, 302-317.

Rosso, P., Ustin, L., and Hastings, A. (2005). Mapping marshland vegetation of San Francisco Bay, California, using hyperspectral data. Int. J. Remote Sens. 26, 5169-5191. doi: 10.1080/01431160500218770

Rouse, W., Haas, H., Schell, A., and Deering, W. (1973). Monitoring vegetation systems in the great plains with ERTS. Washington, DC: NASA SP-351 I, Third ERTS Symposium.

Saravia, D., Farfán, V. R., Gutiérrez, R., De Mendiburu, F., Schafleitner, R., Bonierbale, M., et al. (2016). Yield and physiological response of potatoes indicate different strategies to cope with drought stress and nitrogen fertilization. Am. J. Potato Res. 93, 288-295. doi: 10.1007/s12230-016-9505-9

Schafleitner, R. (2009). Growing more potatoes with less water. Trop. Plant Biol. 2, 111-121. doi: 10.1007/s12042-009-9033-6

Schafleitner, R., Gutierrez Rosales, R. O., Gaudin, A., Alvarado Aliaga, C. A., Martinez, G. N., Tincopa Marca, L. R., et al. (2007). Capturing candidate drought tolerance traits in two native Andean potato clones by transcription profiling of field grown plants under water stress. Plant Physiol. Bioch. 45, 673-690. doi: 10.1016/j.plaphy.2007.06.003

Schapendonk, A., Spitters, C., and Groot, P. (1989). Effects of water stress on photosynthesis and chlorophyll fluorescence of five potato cultivars. Potato Res. 32, 17-32. doi: 10.1007/BF02365814

Shibuya, T., Kano, K., Endo, R., and Kitaya, Y. (2016). Photosynthetic properties and response to drought in cucumber seedlings acclimatized to different vapor-pressure-deficit levels. Hort. J. 86, 334-339. doi: 10.2503/hortj.MI-154

Silva, M. A., dos Santos, M., Jadoski, C., and da Silva, J. (2013). Photosynthetic capacity and water use efficiency in sugarcane genotypes subject to water deficit during early growth phase. Braz. Arch. Biol. Techn. 56, 735-748. doi: 10.1590/S1516-89132013000500004

Solomon, K., and Labuschagne, T. (2004). Variation in water use and transpiration efficiency among durum wheat genotypes grown under moisture stress and non-stress conditions. J. Agric. Sci. 141, 31-41. doi: 10.1017/S0021859603003356

Soltys-Kalina, D., Plich, J., Strzelczyk-Żyta, D., Śliwka, J., and Marczewski, J. (2016). The effect of drought stress on the leaf relative water content and tuber yield of a half-sib family of 'Katahdin'-derived potato cultivars. Breed. Sci. 66, 328-331. doi: 10.1270/jsbbs.66.328

Stark, C., Love, S., King, B., Marshall, J., Bohl, H., and Salaiz, T. (2013). Potato cultivar response to seasonal drought patterns. Am. J. Potato Res. 90, 207-216. doi: 10.1007/s12230-012-9285-9
Taiz, L., and Zeiger, E. (2002). Plant Physiology. Sunderland, MA: Sinauer Associates.

Teixeira, J., and Pereira, S. (2007). High salinity and drought act on an organ-dependent manner on potato glutamine synthetase expression and accumulation. Environ. Exp. Bot. 60, 121-126. doi: 10.1016/j.envexpbot.2006.09.003

Tezara, W., Mitchell, J., Driscoll, S., and Lawlor, D. W. (1999). Water stress inhibits plant photosynthesis by decreasing coupling factor and ATP. Nature 1401, 914-917.

Torres Netto, A., Campostrini, E., Oliveira, J. G., and Bressan-Smith, R. E. (2005). Photosynthetic pigments, nitrogen, chlorophyll a fluorescence and SPAD-502 readings in coffee leaves. Sci. Hort. 104, 199-209. doi: 10.1016/j.scienta.2004.08.013

Trebejo, I., and Midmore, J. (1990). Effect of water stress on potato growth, yield and water use in a hot and a cool tropical climate. J. Agric. Sci. 114, 321-334. doi: $10.1017 /$ S0021859600072713

Tucker, C., and Sellers, P. (1986). Satellite remote sensing of primary production. Int. J. Remote Sens. 7, 1395-1416. doi: 10.1080/01431168608948944

United Nations Development Programme (UNDP). (2010). Human Development Report. The real Wealth of Nations: Pathways to Human Development. New York, NY: UNDP, 20th Anniversary Edition.

Van Evert, F., Van der Voet, P., Van Valkengoed, E., Kooistra, L., and Kempenaar, C. (2012). Satellite-based herbicide rate recommendation for potato haulm killing. Eur. J. Agron. 43, 49-57. doi: 10.1016/j.eja.2012.05.004

Vasquez-Robinet, C., Mane, S. P., Ulanov, A. V., Watkinson, J. I., Stromberg, V. K., De Koeyer, D., et al. (2008). Physiological and molecular adaptations to drought in Andean potato genotypes. J. Exp. Bot. 59, 2109-2123. doi: $10.1093 /$ jxb/ern073

Verhulst, N., and Govaerts, B. (2010). The Normalized Difference Vegetation Index (NDVI) GreenSeekerTM Handheld Sensor: Toward the Integrated Evaluation of Crop Management. Part A: Concepts and case studies. Mexico: CIMMYT.

Vos, J., and Groenwold, J. (1989). Characteristics of photosynthesis and conductance of potato canopies and the effects of cultivar and transient drought. Field Crops Res. 20, 237-250. doi: 10.1016/0378-4290(89)90068-3

Vos, J., and Haverkort, J. (2007). "Water availability and potato crop performance," in Potato Biology and Biotechnology: Advances and Perspectives, ed D. Vreugdenhil (Amsterdam: Elsevier), 333-351.

Vu, V., Gesch, R., Allen, L., Boote, J., and Bowes, G. (1999). CO 2 enrichment delays a rapid, drought-induced decrease in Rubisco small subunit transcript abundance. J. Plant Physiol. 155, 139-142. doi: 10.1016/S0176-1617(99) 80156-4

Walworth, J., and Carling, D. (2002). Tuber initiation and development in irrigated and non-irrigated potatoes. Am. J. Potato Res. 79, 387-395. doi: $10.1007 / \mathrm{BF} 02871683$

Wilkinson, S., and Davies, J. (2002). ABA-based chemical signaling: the coordination of responses to stress in plants. Plant Cell Environ. 25, 195-210. doi: 10.1046/j.0016-8025.2001.00824.x

Xue, L., Cao, W., Luo, W., Dai, T., and Zhu, Y. (2004). Monitoring leaf nitrogen status in rice with canopy spectral reflectance. Agron. J. 96, 135-142. doi: 10.2134/agronj2004.0135

Zhao, D., Reddy, K., Kakani, K., Read, J., and Carter, A. (2003). Corn (Zea mays L.) growth, leaf pigment concentration, photosynthesis and leaf hyperspectral reflectance properties as affected by nitrogen supply. Plant Soil 257, 205-218. doi: 10.1023/A:1026233732507

Zygielbaum, A. (2009). Detection and Measurement of Water Stress in Vegetation Using Visible Spectrum Reflectance. Ph.D. thesis, Lincoln, University of Nebraska.

Conflict of Interest Statement: The authors declare that the research was conducted in the absence of any commercial or financial relationships that could be construed as a potential conflict of interest.

Copyright (C) 2017 Romero, Alarcón, Valbuena and Galeano. This is an open-access article distributed under the terms of the Creative Commons Attribution License (CC $B Y)$. The use, distribution or reproduction in other forums is permitted, provided the original author(s) or licensor are credited and that the original publication in this journal is cited, in accordance with accepted academic practice. No use, distribution or reproduction is permitted which does not comply with these terms. 